\title{
Inward Foreign Direct Investments (FDI) and Location Choice Determinants: Empirical Evidence from India
}

\author{
Sixtus Cyprian Onyekwere ${ }^{\mathrm{a}, *} \&$ Oludamilola Otuyelu ${ }^{\mathrm{b}}$
}

\author{
${ }^{a}$ Department of Humanities, The Regent College Abuja, Nigeria sixtusonyekwere@gmail.com
}

${ }^{b}$ Birmingham Business School, University of Birmingham, Birmingham, UK

\begin{abstract}
The main purpose of this research was to determine the nature of the relationship between inward FDI flow into India and selected sets of FDI location determinants. The paper also investigates the exact impact of the individual FDI location determinants on inward FDI flow into India. Following these objectives, eight variables relating to the inward FDI locational advantage theory were selected, with data running from 1965-2018. The investigated location determinants for inward FDI include tax, market size (GDP), a measure of market potential (GDPPC), human capital (education), wage cost, Ease of Doing Business (DB), and measure of economic progress (GDP growth). The method of data analysis involved the application of OLS regression, taking note of the necessary assumptions for the use of OLS. The results of the study indicate that GDP growth is the only significant FDI location determinant in India, with a positive impact of about 0.57 . This implies that the Indian government should prioritise policies that seek to boost GDP
\end{abstract}

Keywords: FDI Determinants, Time Series, OLS, India, Locational Advantage

\section{Introduction}

The entire world has become a global village, flared up by multinational organisations operating in many emerging and developing economies (Rosetta, 2011). This can be seen from the number and indeed the amount of foreign direct investment (FDI) inflows into both developing and developed economies (Nangpiire, Rodrgues, \& Adam, 2018). One major source of capital inflow for emerging economies is FDI (Insah, 2013). Many factors have been identified to be significant in a country's quest for economic development, but more importantly, it has been argued that government policies such as ease of doing business have an enormous impact on the business environment (Breen \& Gillanders, 2011).

Economists have studied FDI as a phenomenon both empirically and theoretically. A large literature exists that points to a host of factors that attract higher levels of FDI. The main determinants of FDI location suggested by such studies can be classified into the following categories: market-access factors, labour costs, infrastructure, government policies, agglomeration effects (see Dunning (1993) for an extensive review) and market potential effects (Blonigen et al., 2004; Head and Mayer, 2004). A large number of theories exists concerning FDI determinants. The work of Dunning (1977, 1993) explains FDI activities holistically. The author elaborates that firms' FDI behaviour is determined by ownership, location and internalization advantages. Location advantages can be investigated through host country-specific variables, while both ownership and internalization advantages are examined by firm-specific factors (Dunning, 1977, 1993).

Policy prescriptions have been well researched in quite several countries. For example, Scaperlanda \& Maurer, (1969) suggest that FDI respond positively to the market size, and many empirical studies in developing host countries have confirmed this hypothesis. Along the same line, Root and Ahmed (1979), and Bhattacharya et al. (1996) both suggest that a growing market increases the prospectus of market potential and a large market size would generate economies of scale. Also, Djankov, McLiesh and Ramalho (2006) and Gillanders and Whelan (2010) present evidence that the

\footnotetext{
* Corresponding author.

E-mail address: sixtusonyekwere@gmail.com (Sixtus Cyprian Onyekwere)
} 
ease of doing business is good for growth and development (Gillanders \& Whelan, 2010) while Djankov, Freund and Pham (2010) find a significant effect of time delays on trades (Djankov, Freund, \& Pham, Trading on Time, 2010). However, some studies have found empirical evidence and challenges therein (Nielsen et al., 2017). Also, Pan (2003) study on the Chinese economy explained that the exchange rate is not a significant determinant of FDI inflow. Conversely, Sharmiladevi \& Saifilali, (2013) study which focused on the Indian economy using data from the Reserve Bank of India data finds that the exchange rate is significant in attracting FDI into India at a 5\% significance level. Also, it has been argued that lower tax rates compensate MNEs for the positive economic externalities they create for host countries (Lim, 2005).

This study, therefore, aims to provide statistical empirical evidence that can shed more light on the determinant factors that attract FDI to India. The interest of this research rest on the fact that despite all the numerous findings on this topic only a few pieces of research seems to have been carried out on the Indian economy, as many studies seem to base their studies on developed economies of the EU countries. The issues of FDI determinants are becoming more important, with emphasis on ease of doing business thus it requires theoretical and empirical investigations. In addition, after the 2007 global financial crisis, FDI has picked up and is growing faster than imagined with the international foreign direct investment inflows increased by $9 \%$ between 2012 and 2013 to $\$ 1.45$ trillion is according to the World Investment Report (UNICTAD, 2014). Additionally, the countries where these studies have been widely conducted have different economic policies and government structures from India. Therefore, it will be justifiable to conduct this study taking into account the uniqueness and peculiarity of the Indian economy.

After an extensive and careful review of the related literature, this study observed that firstly, there is no consensus on the determinants of foreign direct investment. Also, most of the study has been done for developed economies. Furthermore, there are very few studies that discussed the impact of ease of doing business on inward FDI throughout India. Additionally, there are still mixed empirical supports on the factors constituting FDI locational advantage. This controversy motivates this research to include the selected sets of determinants as a variable of interest on the impact of FDI inflows in India where there appears to be less empirical evidence. This study considered these selected sets of variables as key determinants as they feature predominantly in most papers reviewed with mixed results in different countries. Therefore, this paper addresses the questions of whether or not there is a relationship between the selected set of determinants and foreign direct investment in India on one hand, while on the other hand, it identifies and ascertains the impact of these determinants on foreign direct investment in India.

This study is very important to both policymakers and academic practitioners. To the policymakers, the empirical evidence from this study will provide them with the framework in making policies within the context of ease of doing business that will attract more FDIs to the Indian economy. To the academic practitioners, this study can be a starting point for further research on the relationship between ease of doing and foreign direct investment.

\section{Data and Methodology}

This research is set to investigate the impact of seven selected FDI determinants on inward FDI flow into India. The variables include exchange rate (Indian rupee to USD), Doing Business, market size (GDP as proxy) human capital (proxy by secondary school enrolment), tax (gotten as \%GDP), market potential (proxy by GDP Per Capita), economic progress (proxy by GDP growth rate), wage cost and inward FDI (gotten as \% GDP). The variables were chosen in line with existing studies on this topic

\subsection{Data}

All the data were obtained from World Bank indicators from the period 1960-2018. However, because doing business is a newly introduced concept, the data is only available from 2006-2018 on the World Bank website. World Bank indicators have been generally used and trusted for research around the world. All the variables were obtained in their constant form, to reflect their time values. The variables and their abbreviations are as follows:

- $\mathbf{F D I}=$ inward foreign direct investment as a percentage of GDP

- $\mathbf{E X C H = ~ f o r e i g n ~ e x c h a n g e ~ r a t e ~ g o t t e n ~ a s ~ I n d i a n ~ R u p e e ~ t o ~ U S D ~}$

- $\quad \mathbf{D B}=$ Ease of doing business index

- $\quad \mathbf{G D P}=$ gross domestic product in constant prices

- $\quad \mathbf{E D U}=$ secondary school enrolment

- $\quad$ GDPPC $=$ GDP per capita in constant prices

- GDP growth= yearly growth rate of GDP 
- WAGE= wage cost in constant prices

- $\mathbf{T A X}=$ tax revenue as a percentage of GDP

To ensure that all variables are expressed in the same unit for uniformity, the natural log of the variables were used, except for exchange rate, wage rate and GDP growth. This is because; such variables (exchange rate, wage rate and GDP growth) are already in the growth rate form thus, log transformation was not required. Nevertheless, as strongly advised in Kinuthia \& Murshed, (2015) all the variables were further transformed to their first difference form to remove the presence of unit root. According to Kinuthia \& Murshed (2015) the presence of unit root in data biases the estimates obtained.

\subsection{Methodology}

Many authors researching on this topic such as Kyrkilis \& Pantelidis (2003), Kinuthia \& Murshed (2015), DU, LU, \& TAO, (2008), and many others have widely applied simple Ordinary Least Squares (OLS) estimation technique. OLS estimation is used to measure the impact of one variable, ' $\mathrm{X}$ ' on another Variable ' $\mathrm{Y}$ '. The basic form of the technique is given as,

$$
\mathbf{Y}=\mathbf{b}_{0}+\mathbf{b}_{1} \mathbf{X}_{1}+\mathbf{U}
$$

Where $\mathbf{Y}=$ the dependent variable (the main variable one seeks to explain)

$\mathbf{b}_{\mathbf{0}}=$ the intercept parameter, which states what happens to $\mathbf{Y}$ when variable $\mathbf{X}$ is zero

$\mathbf{b}_{1}=$ the estimated value of $\mathbf{Y}$ when $\mathbf{X}_{\mathbf{1}}$ increase by 1 unit

$\mathbf{X}_{\mathbf{1}}=$ the explanatory variable (or independent variable)

$\mathbf{U}=$ the error term. This accounts for the effect of all other variables that may also affect $\mathbf{Y}$ but are not included in the specification

Because the interest of the researcher is to assess the determinants of inward FDI, the variable 'inward FDI' becomes the main variable or the dependent variable $\mathbf{Y}$, while all other locational determinant factors become the explanatory variables $\mathbf{X}_{\mathbf{1}}, \mathbf{X}_{\mathbf{2}}, \mathbf{X}_{\mathbf{3}}, \ldots . . \mathbf{X n}$. Adopting the OLS model described for this present research gives the following framework:

$\mathrm{FDI}=\mathrm{b}_{0}+\mathrm{b}_{1} \mathrm{EXCH}+\mathrm{b}_{2} \mathrm{DB}+\mathrm{b}_{3} \mathrm{GDP}+\mathrm{b}_{4} \mathrm{EDU}+\mathrm{b}_{5} \mathrm{GDPPC}+\mathrm{b}_{6} \mathrm{GDPgrowth}+\mathrm{b}_{7} \mathrm{WAGE}+\mathrm{b}_{8} \mathrm{TAX}+\mathrm{U}$

However, because of the transformations applied to the data (first differenced and logarithmic transformations), the true nature of the specification in equation (2) resembles the form below,

\section{$\mathrm{D}(\ln F D I)=\mathrm{b}_{0}+\mathrm{b}_{1} \mathrm{D}(\mathrm{EXCH})+\mathrm{b}_{2} \mathrm{D}(\operatorname{lnDB})+\mathrm{b}_{3} \mathrm{D}(\operatorname{lnGDP})+\mathrm{b}_{4} \mathrm{D}(\ln \mathrm{EDU})+\mathrm{b}_{5} \mathrm{D}(\operatorname{lnGDPPC})+\mathrm{b}_{6} \mathrm{D}($ GDPgrowth $)$ $+\mathbf{b}_{7} \mathbf{D}($ WAGE $)+\mathbf{b}_{8} \mathrm{D}(\mathrm{TAX})+\mathbf{U} \ldots(3)$}

Equation 3 thus, becomes the final specification for estimation. The interpretation of the coefficients of the multiple linear regression model is a little different from the single variable model. For instance, from equation (3), $b_{1}$ is interpreted as the value of FDI when the exchange rate increases by $1 \%$, while other variables in the model are held constant. This logic applies to all the explanatory variables

Nonetheless, Gujarati \& Porter (2010) explain that for the estimates of OLS regression to be useful, they must satisfy at least, three basic assumptions. First, the residuals must be free from autocorrelation. Secondly, the residuals must be homoscedastic. Thirdly, the residuals must follow a normal distribution. Other assumptions which are also useful to assess the variables are misspecification, multicollinearity and unit root problem. These assumptions are tested in section 4 of this paper using the recommended tests outlined in Kyrkilis \& Pantelidis (2003), Gujarati \& Porter (2010) and Kinuthia \& Murshed (2015).

\section{Results and Discussion}

Recall that the focus of this paper is to assess the nature of the relationship and impact of eight selected location determinants of FDI, on inward FDI into India. Following the procedures outlined in section 2, this section presents the analysis and findings

\subsection{Evolution of Series and Descriptive Statistics}


EXCH

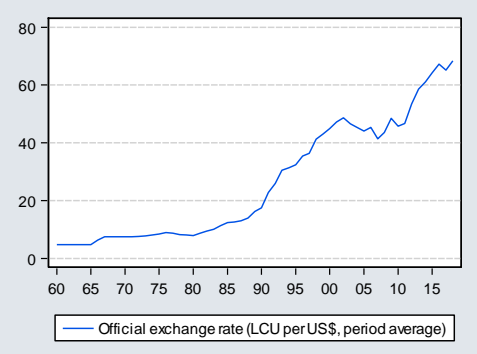

LNDB

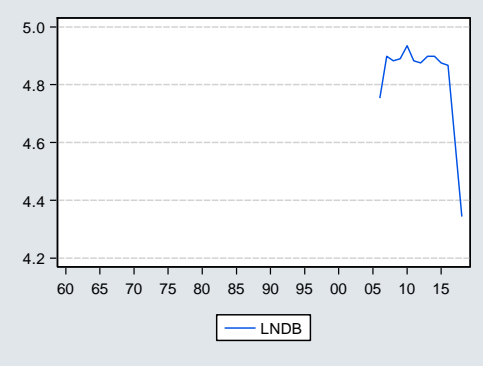

LNGDPPC

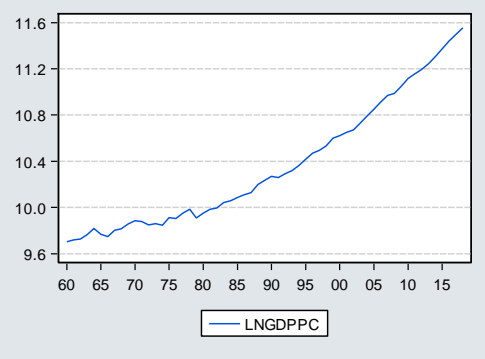

FDI - Net \%GDP

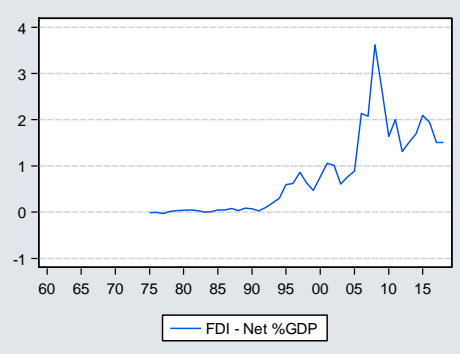

LNEDU

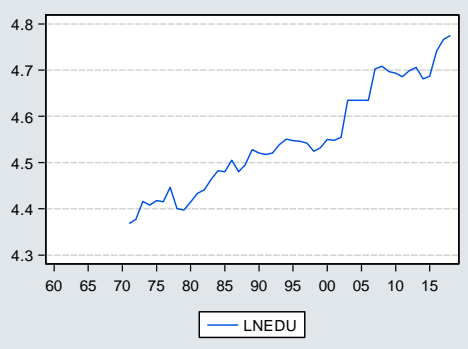

Wage

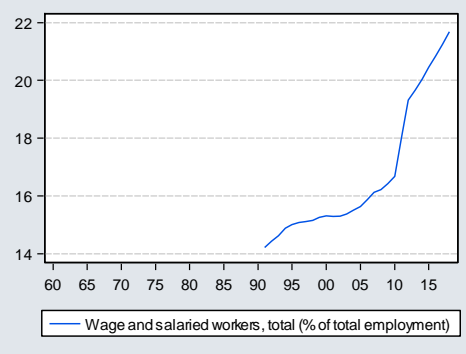

GDP growth (annual \%)

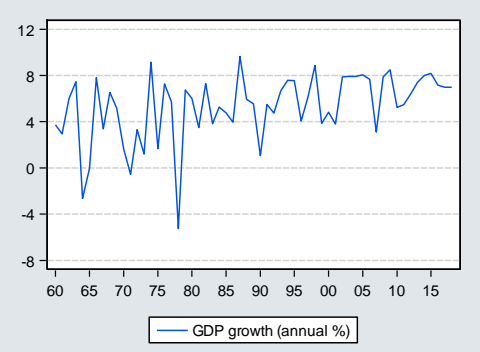

LNGDP

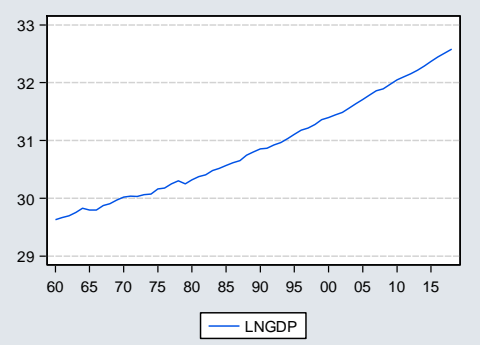

Tax revenue (\% of GDP)

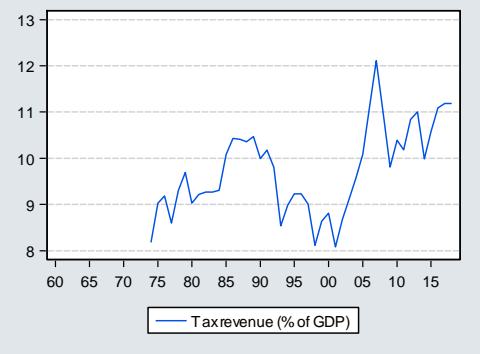

Figure 1. Evolution of the Series

Figure 1 shows the evolution of the series for the individual variables. Although the variables have different starting points in time, the observation period for all variables ended in 2018. Data for doing business started only from 20062018, and that of wage from 1990-2018. Other variables started from 1960-2018. From visual inspection of the individual graphs, it can be noticed that as expected, there are different patterns observed. Nevertheless, taking a guide from the location advantage theory, careful consideration is given to FDI concerning the movement of all other variables. One would expect that except for Doing Business, Exchange rate, Tax and Wage cost, other variables (GDP, GDPPC, GDP growth, and EDU) should have a positive relationship with FDI. That is, an increase in FDI should mean that the market has become more attractive. Although the Exchange rate can be positive or negative, Doing Business, tax and wage cost should have a negative relationship with FDI because increasing trend means the market is unattractive thus, FDI should decrease according to theory. However, evidence from visual inspection tells a little different story. For easy analysis, we take two significant points in time (2005-2007 and 2008- 2010) in the behaviour of FDI to compare with changes in the explanatory variables. From 2005-2007, one can observe a very high increase in inward FDI flow to India. For the periods 2005-2007 when FDI was rising, exchange was decreasing which means economic sense because as less and less Rupee was needed to exchange for 1US dollar it becomes cheaper to invest. Again, Doing Business was also falling in the period which meant that it becomes easier and easier to establish a business in India, and tax was also falling. Again, between 2008-2010 when FDI was falling, one can also observe a rising trend in the exchange rate which means that the Rupee was losing value. During the period, there was also a rising trend in Doing Business, as well as a rising tax rate thus, making the market unattractive. Nonetheless, one cannot say the same for other variables, as there is no agreement with theory. For instance, GDPPC, GDP growth, and wage have observed a consistent pattern irrespective of what is happening with FDI, indicating some signs of no correlation. Nonetheless, these relationships are further assessed using empirical analysis, which provides the true picture 
Table 1. Descriptive Statistics

\begin{tabular}{|c|c|c|c|c|c|c|c|c|c|}
\hline & FDI & GDP_GROWTH & LNDB & LNEDU & LNGDP & LNGDPPC & WAGES & $\mathrm{EXCH}$ & TAX \\
\hline Mean & 0.796742 & 5.290753 & 4.815726 & 4.550890 & 30.89755 & 10.36618 & 16.73868 & 26.37150 & 9.739127 \\
\hline Median & 0.600438 & 5.947343 & 4.882802 & 4.535295 & 30.80184 & 10.23484 & 15.56600 & 16.22550 & 9.689049 \\
\hline Skewness & 1.099838 & -1.285887 & -2.091823 & 0.292061 & 0.323156 & 0.644882 & 0.971362 & 0.522690 & 0.268610 \\
\hline Kurtosis & 3.656455 & 4.957022 & 6.226456 & 1.942538 & 1.862563 & 2.150870 & 2.396233 & 1.827423 & 2.404540 \\
\hline Jarque-Bera & 9.660770 & 25.67473 & 15.11949 & 2.918849 & 4.207391 & 5.861929 & 4.828499 & 6.066565 & 1.205957 \\
\hline Probability & 0.007983 & 0.000003 & 0.000521 & 0.232370 & 0.122005 & 0.053346 & 0.089434 & 0.048157 & 0.547179 \\
\hline
\end{tabular}

Table 1 above gives an idea of the nature of the data obtained. The mean values give the average of the rate of change in the data for the individual observation period. A glance at the values of skewness and kurtosis gives a hint at the normality of the data. As a rule of thumb, skewness must be zero and kurtosis 3 for a variable to be said to be normally distributed Gujarati \& Porter (2010). However, the values obtained differ from 0 and 3, which indicates that none of the variables is normally distributed. Nevertheless, the Jarque-Bera statistics which is a formal test of normality has a little different opinion here. The Jarque-Bera statistics assumes a null hypothesis that the variable is normally distributed. Failure to reject this hypothesis can only occur when the probability value which accompanies the JarqueBera statistic is greater than 0.05 . From the probability values for the individual variables, one can observe that only five variables Edu, Tax, GDP, GDPPC, and Wage Cost have p-values greater than 0.05 thus, we fail to reject the null hypothesis which states that variables are normally distributed. The rest variables have p-values below 0.05 thus, do not follow a normal distribution. The consequence of using variables that do not follow normal distribution for regression analysis is usually a spurious regression Kinuthia \& Murshed (2015). Nonetheless, the central limit theorem still permits the use of variables that do not follow normal distribution for regression, arguing that normality is a question of the type of sample one obtains (Gujarati \& Porter, 2010). They further explain that it is possible that if a different sample was drawn from the population, one could obtain normally distributed data. Thus, based on this theory, we still proceed with all the variables for further analysis.

\subsection{Unit Root test}

The unit root is a concept used to assess the stationarity of variables. That is if variables possess constant mean and variance over time. It is argued that using variables that do not possess constant mean and variance for regression might lead to a spurious regression, which is common in OLS regressions when data is used in the level. Taking this into consideration, all variables were transformed to their first difference form to make them stationary. However, to confirm if differencing has removed the unit root problem, a formal test recommended in Gujarati \& Porter (2010) and was also used by Kinuthia \& Murshed (2015) is the Augmented Dickey-Fuller test. The null hypothesis for this test states that series have a unit root (that is, do not have constant mean and variance), while the alternative hypothesis says otherwise. The test is conducted at a 5\% significance level with intercept and trend. Table 2 below gives the result of the test.

Table 2. ADF Test for Unit Root

\begin{tabular}{lcc}
\hline Method & Statistic & Prob.** \\
\hline ADF - Fisher Chi-square & 191.174 & 0.0000 \\
ADF - Choi Z-stat & -11.2445 & 0.0000 \\
\hline \hline
\end{tabular}

As can be seen in table 2 above, all the variables were entered for the test. As shown in the table, both the ADF-Fisher Chi-square and the Choi Z-stat produced p-values that are less than 0.05 thus, a rejection of the null hypothesis. Thus, the inference is drawn that the series has now observed constant mean and variance. In other words, they have become stationary. To have a visual inspection of the transformed series, see figure 2 . 


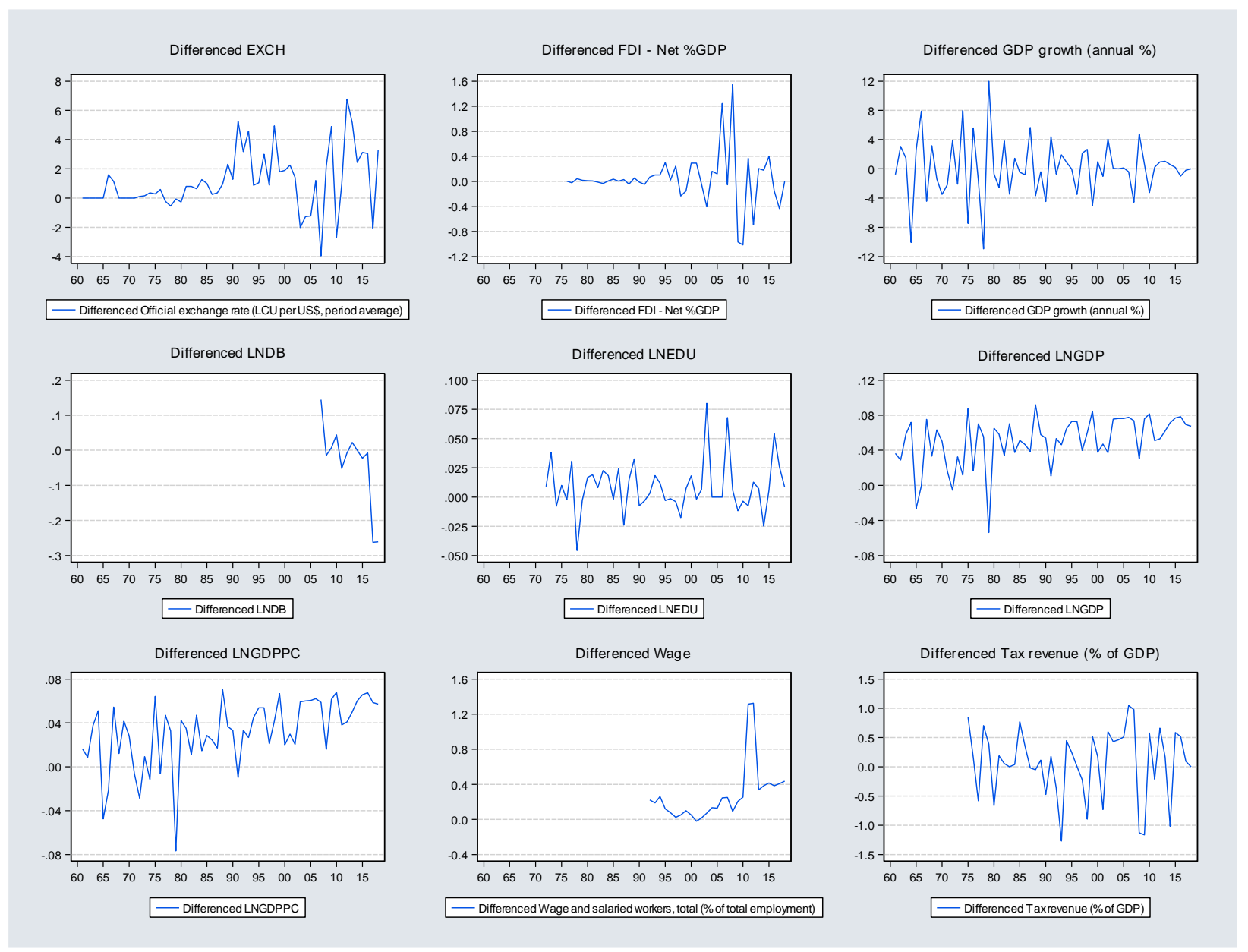

Figure 2. The Stationary Series

As can be observed in figure 2 above, there is a more constant mean and variance compared to the graph previously placed in figure 1 earlier. Thus, we can be confident to proceed with the differenced variables for OLS estimation

\subsection{Pearson Correlation test for Multicollinearity, and Ramsey-Reset Test for Misspecification}

Before carrying out OLS regression analysis, it is often advised to assess multicollinearity and misspecification tests. The essence of the multicollinearity test is to ensure that we are not using explanatory variables which can stand in for one another. That is, avoid using variables that are highly correlated with one another. The danger in it is that, if two variables are highly correlated, it would render them insignificant; meanwhile, they are significant explanatory variables if one is removed. For misspecification, we want to make sure the specification has the correct linear functional form intended for the OLS estimate. If for example, the explanatory variables have a non-linear relationship while we assume a linear relationship and proceed with the regression, the results obtained would be misleading. Thus, these two preregression tests are highly important. Firstly, we test for multicollinearity using the Pearson correlation analysis shown in table 3 below. Note that to test for multicollinearity, the dependent variable FDI is removed. Only the explanatory variables are included

Table 3. Pearson Correlation Test for Multicollinearity

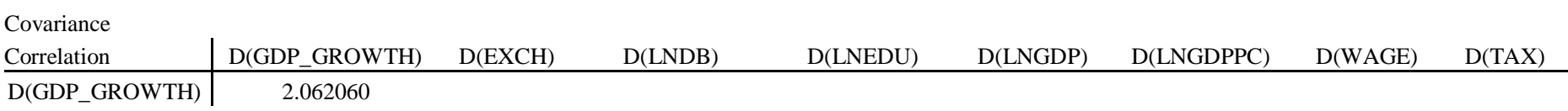




\begin{tabular}{|c|c|c|c|c|c|c|c|c|}
\hline & 1.000000 & & & & & & & \\
\hline \multirow{2}{*}{$\mathrm{D}(\mathrm{EXCH})$} & 5.860863 & 90.33868 & & & & & & \\
\hline & 0.429412 & 1.000000 & & & & & & \\
\hline \multirow[t]{2}{*}{$\mathrm{D}(\mathrm{LNDB})$} & -0.025840 & -0.770620 & 0.025351 & & & & & \\
\hline & -0.113018 & -0.509225 & 1.000000 & & & & & \\
\hline \multirow[t]{2}{*}{$\mathrm{D}(\mathrm{LNEDU})$} & -0.002437 & 0.207975 & -0.003580 & 0.001269 & & & & \\
\hline & -0.047643 & 0.614244 & -0.631136 & 1.000000 & & & & \\
\hline \multirow[t]{2}{*}{$\mathrm{D}$ (LNGDP) } & 0.087385 & 2.235879 & -0.021639 & 0.006489 & 0.060805 & & & \\
\hline & 0.246785 & 0.953986 & -0.551144 & 0.738677 & 1.000000 & & & \\
\hline \multirow[t]{2}{*}{ D(LNGDPPC) } & 0.069206 & 1.820002 & -0.018063 & 0.005318 & 0.049473 & 0.040277 & & \\
\hline & 0.240138 & 0.954123 & -0.565298 & 0.743887 & 0.999701 & 1.000000 & & \\
\hline \multirow[t]{2}{*}{ D(WAGE) } & 0.836643 & 19.13789 & -0.166378 & 0.048288 & 0.501362 & 0.407206 & 4.354796 & \\
\hline & 0.279194 & 0.964880 & -0.500746 & 0.649560 & 0.974313 & 0.972298 & 1.000000 & \\
\hline \multirow[t]{2}{*}{$\mathrm{D}(\mathrm{TAX})$} & -0.425258 & -0.108303 & -0.028732 & 0.006448 & -0.003966 & -0.001421 & 0.018218 & 0.347981 \\
\hline & -0.502023 & -0.019316 & -0.305910 & 0.306848 & -0.027266 & -0.011999 & 0.014799 & 1.000000 \\
\hline
\end{tabular}

From the correlation table, it can be noticed, a very high correlation between GDP and GDP per capita, GDP and exchange rate, wage and exchange. From this, indications are that the exchange rate poses a serious problem to the model, as almost all the variables have a correlation of $90 \%$ and above with it. According to the explanation in Gujarati \& Porter (2010) including exchange in the regression in this kind of situation may cause variables that would have been significant to become insignificant. Nevertheless, many other papers in the literature review have introduced exchange rates together with similar variables. Thus, one can follow previous papers to also include exchange rates. Furthermore, the exchange rate is an important determinant of inward FDI according to locational advantage theory. Thus, excluding it in the regression may be as equally beneficial. Nonetheless, since there is no exact or perfect collinearity, one can still include the exchange rate in the model. However, the consequence of this would be that $\mathrm{R}^{2}$ value would be higher than it ordinarily should be. Thus, the researcher acknowledges this problem and interprets the $\mathrm{R}^{2}$ value with caution.

Having addressed the problem of multicollinearity, the next assessment would is to determine if our model has the correct functional form. That is if the model is linear in its parameters. To do this, we employ the Ramsey RESET Test. The null hypothesis of the model states that the model is linear in its parameters, while the alternative hypothesis states otherwise. The test is carried out in form of an F-test at a 5\% level of Significance. If the p-value following the Fstatistic is greater than 0.05 , then we fail to reject the null hypothesis. The result of the test is placed in table 4 below

Table 4. Ramsey RESET Test for Misspecification

\begin{tabular}{lccc}
\hline \hline & Value & df & Probability \\
\hline t-statistic & 2.347321 & 3 & 0.1006 \\
F-statistic & 5.509916 & $(1,3)$ & $\mathbf{0 . 1 0 0 6}$ \\
Likelihood ratio & 13.55406 & 1 & 0.0002 \\
\hline \hline
\end{tabular}

From table 4 above, it can be noticed that the p-value corresponding to the F-statistic is greater than 0.05 thus, we fail to reject the null hypothesis which states that the model is linear in its parameters and thus, has the correct functional form. By this, we proceed with the regression analysis using the model

\subsection{OLS Regression Estimates and Post Regression Tests (autocorrelation, heteroskedasticity, and normality)}


Table 5 below gives the result of the OLS estimate. However, to ensure that this estimate is not biased, there is a need to assess autocorrelation, heteroskedasticity and normality of the residuals from the regression.

According to Gujarati \& Porter (2010), the problem of autocorrelation can be assessed using Durbin-Watson statistics which can also be found in table 5 below. If there was a lag in the variable, a more appropriate test of serial correlation would have been the famous LM test. Thus, as no lag variable was introduced, Durbin-Watson statistics becomes an appropriate test. As a rule of thumb, the Durbin Watson statistic of 2 or approximately 2 indicates the absence of autocorrelation. As can be found in table 5 below, the Durbin Watson statistic assumes the value of 2, indicating the absence of autocorrelation in the model. To assess heteroskedasticity and normality, a different calculation and test are required. See table 6 and figure 3 below for these tests

Dependent Variable: Inward FDI

Table 5: OLS Regression

\begin{tabular}{|c|c|c|c|c|c|c|}
\hline Variable & Coefficient & Std. Error & t-Statistic & Probability & R Squared & $\begin{array}{c}\text { Durbin- } \\
\text { Watson Stat }\end{array}$ \\
\hline D(EXCH) & -0.165970 & 0.137049 & -1.211028 & 0.2925 & 0.787 & 2.33 \\
\hline D(LNDB) & 2.882369 & 2.249263 & 1.281473 & 0.2693 & & \\
\hline D(LNGDP) & -56.67903 & 80.54131 & -0.703726 & 0.5204 & & \\
\hline D(LNEDU) & 8.252731 & 12.29870 & 0.671025 & 0.5390 & & \\
\hline D(LNGDPPC) & 73.37213 & 95.22919 & 0.770479 & 0.4840 & & \\
\hline $\begin{array}{c}\text { D(GDP_GROWT } \\
\text { H) }\end{array}$ & 0.565348 & 0.263023 & 2.149427 & 0.0980 & & \\
\hline D(WAGE) & 0.138026 & 0.786408 & 0.175515 & 0.8692 & & \\
\hline D(TAX) & 0.291217 & 0.711838 & 0.409106 & 0.7034 & & \\
\hline
\end{tabular}

Table 6: Breusch Godfrey Test for Heteroskedasticity Heteroskedasticity Test: Breusch-Pagan-Godfrey

\begin{tabular}{llll}
\hline \hline F-statistic & 1.078649 & Prob. F(8,4) & $\mathbf{0 . 5 0 5 9}$ \\
Obs*R-squared & 8.882554 & Prob. Chi-Square(8) & 0.3523 \\
Scaled explained SS & 0.314524 & Prob. Chi-Square(8) & 1.0000 \\
\hline \hline
\end{tabular}

Table 6 above represents the test for Heteroskedasticity. Since the null hypothesis is that the residuals are homoscedastic (that is, the residuals maintain a constant variance across time), the F-statistic p-value of 0.5059 indicates that we will fail to reject this null at 5\% significance level. We therefore conclude that the residuals are homoscedastic.

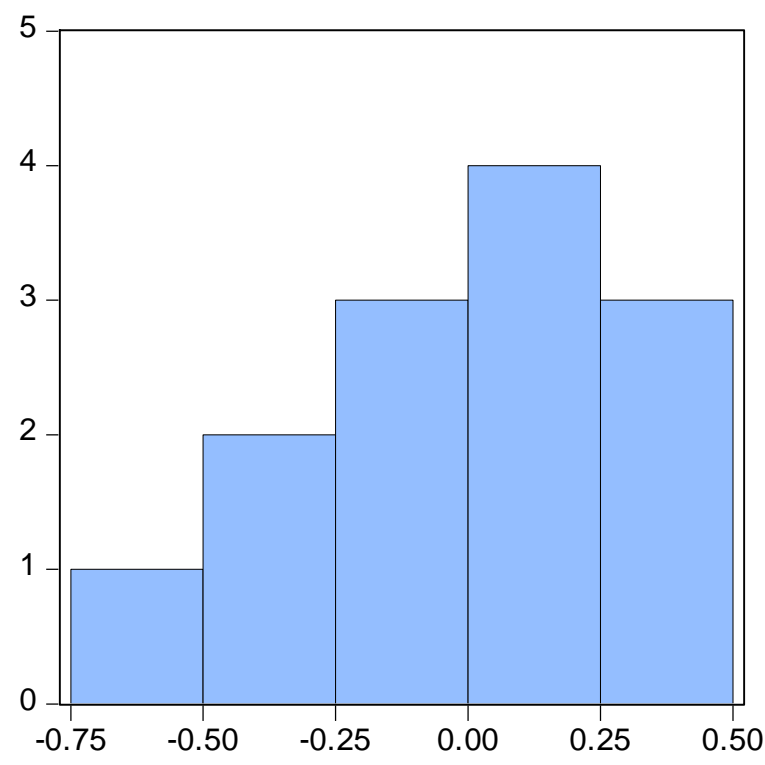

\begin{tabular}{|lc|}
\hline \multicolumn{2}{|l|}{ Series: Residuals } \\
Sample 2006 2018 \\
Observations & 13 \\
& \\
Mean & $3.36 \mathrm{e}-13$ \\
Median & 0.078534 \\
Maximum & 0.310092 \\
Minimum & -0.512193 \\
Std. Dev. & 0.282626 \\
Skewness & -0.402714 \\
Kurtosis & 1.748020 \\
& \\
Jarque-Bera & 1.200424 \\
Probability & 0.548695 \\
\hline
\end{tabular}


Figure 3. Jarque-Bera Test for Normality

Figure 3 above shows the test for normality. The null hypothesis of the Jarque-Bera test is that the residuals follow a normal distribution, while the alternative hypothesis states otherwise. The test is carried out at a 5\% level of significance, where a probability value for the Jarque-Bera statistic above 0.05 would lead to a failure to reject the null hypothesis. As can be seen in the table, the probability value is 0.549 , which leads to the failure to reject the null hypothesis. Thus, the inference is drawing that the residuals are normally distributed.

Haven tested all the necessary assumptions successfully, and found no problems in the residuals; we now proceed to interpret the OLS regression estimate to find answers to the research questions posed

\subsection{Interpretation of Regression Estimates}

Referring back to table 5 above, we extract the estimates from the regression on table 5 and place them on table 7 below for easy access to the information produced.

A first glance at the information in table 7 above would immediately show the signs attached to the coefficients. One can observe that Exchange rate, education (which represents human capital), GDPPC and GDP growth have their expected signs. From the coefficients of variables with the expected signs, it can be observed that the exchange rate has an impact of $-0.17 \%$ on FDI, education (human capital) has an impact of $8 \%$ on FDI, GDPPC $73 \%$ and GDP growth $0.57 \%$. However, only GDP growth is significant at $10 \%$ which means that it is the only variables one can be confident in making use of its result. Nevertheless, this widespread insignificance may have been caused by the multicollinearity caused by the exchange rate variable. On the other hand, the sign attached to GDP, Wage, Tax and Doing Business are contrary to the expected signs and thus, hard to interpret. For instance, it is difficult to explain why inward FDI would fall with rising GDP, but increase with the rise in tax, wage and doing business. But since the p-values associated with these variables are insignificant, not much importance is attached to the unexpected signs.

Table 7. Extracted Regression Estimates

\begin{tabular}{|c|c|c|c|c|c|c|}
\hline Variable & Coefficient & Std. Error & t-Statistic & Probability & R Squared & $\begin{array}{c}\text { Durbin- } \\
\text { Watson Stat }\end{array}$ \\
\hline D(EXCH) & -0.165970 & 0.137049 & -1.211028 & 0.2925 & $\mathbf{0 . 7 8 7}$ & $\mathbf{2 . 3 3}$ \\
\hline D(LNDB) & 2.882369 & 2.249263 & 1.281473 & 0.2693 & \\
\\
\hline D(LNGDP) & -56.67903 & 80.54131 & -0.703726 & 0.5204 \\
\hline D(LNEDU) & 8.252731 & 12.29870 & 0.671025 & 0.5390 \\
\hline D(LNGDPPC) & 73.37213 & 95.22919 & 0.770479 & 0.4840 \\
D(GDP_GROWT & & & & & \\
(H) & 0.565348 & 0.263023 & 2.149427 & $\mathbf{0 . 0 9 8 0}$ \\
\cline { 1 - 3 } D(WAGE) & 0.138026 & 0.786408 & 0.175515 & 0.8692 \\
\hline
\end{tabular}

Generally, judging from the probability values, it can be concluded that economic GDP growth is the only significant variable attracting investors into India for investments. According to the coefficient of 0.57 computed, it means that holding all other variables included in the model constant, a $1 \%$ increase in GDP growth leads to about $57 \%$ increase in inward FDI flow into India. This appears to be a very high estimate for just a single explanatory variable. However, judging from the rigorousness of the model, this result may be accurate. In addition, $\mathrm{R}^{2}$ statistic of 0.787 means that the model has explained about $79 \%$ of the variations in inward FDI flow into India. However, judging from the multicollinearity problem previously identifies, the R2 may be lower than the computed value, but the real value should not be very far off from the computed value.

With this result, the research questions posed in chapter 1 can be successfully answered. That is, except for economic growth (GDP growth) which has a significant positive relationship and impact of 57\%, other variables such as exchange rate, doing business, market size (GDP), human capital(education), and wage cost do not have a significant impact on inward FDI flow into India. In other words, it means that changes in these variables do not in any way, affect inward FDI flow into India. 
Nonetheless, there is an interest to compare findings of this present with what has been reported in the previous papers to give support to this paper. Starting with the result for wage cost, this present research found that wage cost is positively related to inward FDI. Although this relationship was not significant, we believe that a high correlation between the explanatory variables may have had a hand in it. However, other authors who also reported an insignificant relationship between inward FDI and wage cost are Broadman and Sun (1997), Chen (1996), and Head and Ries (1996). Nevertheless, the positive sign accompanying the coefficient for wage cost in this present research does indicate some sort of positive relationship between FDI and wage cost, which is consistent with the work of Zhao \& Zhu (2000), and He (2001). The authors explain that this positive relationship can be linked to the quality of labour, as high labour costs indicate the wage demands by highly trained and skilled staff. The more skill and experience the staff possess, the higher wages they can command. Thus, it is no surprise that higher wages would attract more inward FDI.

Still, the positive relationship found for inward FDI and Wage Cost is highly disputed by authors such as FDI Belderbos and Carree (2002), Cheng and Kwan (2000), Fung, lizaka, and Parker (2002), Wei and Liu (2001), Zhao and Zhu (2000), Cassidy (2002) and Wei et al. (1999). These authors found a contradicting result, inferring a negative relationship. The authors argue that investors are deterred by locations with high wages.

Turning to human capital, a positive relationship between human capital (education as proxy) and inward FDI was found. As of the time of this research, only a few empirical papers have included human capital in their study. The papers found which added this variable are DU, LU, \& TAO (2008) Kyrkilis \& Pantelidis (2003), and Belkhodja, Mohiuddin, \& Karuranga (2017). The result of the authors is in agreement with that of this study. Thus, one can conclude that human capital has a positive relationship with inward FDI

Market Size (GDP), Potential (GDPPC) and GDP growth have been widely investigated in empirical studies. These three variables are closely related and are usually highly correlated with one another. Out of the three, this present research found only GDP growth to have a significant positive impact on inward FDI. GDPPC also produced a positive sign which is also expected but insignificant. The concern was GDP producing a negative relationship though insignificant. The only found paper that agrees with this finding is Dauti (2009). The author also reports a negative relationship for GDP is Dauti (2009). The paper goes further to infer that GDPPC and GDP growth also have a negative relationship with inward FDI. Except for Dauti (2009), all papers found incorporating these variables in their work such as Xu and Yeh (2013), Kyrkilis \& Pantelidis (2003), Botric \& Škuflic (2006), Erdal \& Tatoglu (2002), Boateng, \& Bampoe (2015), and many others, report positive relationships for GDP, GDPPC and GDP growth. The explanation that can be given to this negative relationship found for GDP in this paper can be drawn from the argument of Dauti (2009). The author explains that the bases of the economic climate and corrupt practices concerning government expenditures being done for FDI attraction motives may be the cause of this negative relationship. In addition to this, high GDP sometimes does not always mean a better economic environment. Thus, these may explain the reason for this negative relationship between GDP and inward FDI flow into India

The result obtained for ease of doing business from this research, on the other hand, is very abstract. This paper found a positive relationship though insignificant. From the nature of data obtained from the World Bank doing business index, a higher score indicates a worse (unattractive) business environment while a low score means a friendly (attractive) business environment. Following this, the positive sign accompanying the coefficient means that an increase in score leads to an increase in inward FDI. In other words, it means that when India is poorly ranked in the World Bank's rank, more inward FDI is attracted and vice versa which is highly controversial. This result goes against all the previous studies discussed in the literature review. It is difficult to explain the reason for the contrary result obtained in this study. Nevertheless, the reason may be the new restructuring of the Indian business environment which led to a massive improvement in the ease of doing business index in 2018. There is a possibility that this restructuring done was a government agenda, to trick World bank to place India in a better position in a bid to attract foreign investment meanwhile, running a business in the country has become worse. Thus, investors pull out on the notice of this hidden agenda, which explain why improving doing business score is reducing inward FDI in India. Moreover, this negative relationship is insignificant, which means that the result obtained from this variable is nothing to worry about.

Moving on to the tax variable results from this present research indicate that tax has a positive relationship with inward FDI (although this is also not significant). Other papers that also obtained an insignificant estimate for tax are, Chakrabarti (2001), Mody (1992), and Javorcik (2004), which agrees with the result in this present research. However, judging from the sign attached to the estimate for tax in this present research, it may be inferred that there is some sort of positive relationship. That is, an increase in tax revenue leads to an increase in inward FDI in India. As surprising as 
this might seem, many papers have also found support that increasing tax revenue increases inward FDI. The papers include Swenson (1994), and Zafarc, Shafqueb, \& Liu, (2019). An explanation for this may be that, according to accounting practices, higher tax is usually associated with higher profit, Thus, a positive relationship between tax and inward FDI. Nevertheless, other papers who dispute this finding are Rolfe, Ricks, Pointer \& McCarthy (1993), Sethi et al. (2002), Javorcik \& Spatareanu (2005), Wei (2000), Chung \& Alcácer (2002), Carstensen \& Toubal, (2004), and De Mooij and Ederveen (2003). The authors found a negative relationship between tax and inward FDI, arguing that investors are attracted by locations with lower tax rates. However, judging from the time lag between when these papers are done and recent papers such as Zafarc, Shafqueb, \& Liu, (2019) and that of this present research, a case can be built that changing market conditions may have caused this change from the negative relationship in earlier studies to the positive relationship in recent studies.

Lastly, results from the exchange turned out as expected. This present research found a negative relationship between exchange rate and inward FDI in India. This means that as the Rupee is losing value against the US Dollar, more and more foreign direct investment is attracted to India. This negative relationship is consistent with findings in all previous papers found such as Froot \& Stein, (1991), Jaratin et al (2010), Caves (1989), Kogut and Chang (1996), Blonigen (1997), and many others

\section{Conclusion}

The purpose of this research has been to accomplish two objectives. Firstly, to determine the nature of the relationship between inward FDI flow into India and selected sets of FDI location determinants. Secondly, to investigate the impact of the individual FDI location determinants on inward FDI flow into India. Following these objectives, eight variables relating to the inward FDI locational advantage theory were selected. They include tax, market size (GDP) measure of market potential (GDPPC), human capital (education), wage cost, Ease of Doing Business (DB), and measure of economic progress (GDP growth). The observation runs from 1960-2018. However, during regression, the observation was cut down from 2006-2018 because of the inclusion of doing business data which is only available from 2006 . The method of data analysis involved the application of OLS regression, making sure the conditions of CLRM are met. The results of this study, therefore, provide the following answer to research questions placed on 5.1 and 5.2

\subsection{The nature of the relationship between inward FDI flow into India and the selected determinants}

Table 8 below has been constructed to aid with an easier assessment of the regression results to understand the question under scrutiny

Table 8. Relationship between Inward FDI and the Selected Sets of Location Determinants

\begin{tabular}{|l|l|l|l|}
\hline S/N & Variable & Expected Sign & Actual Sign \\
\hline 1 & FDI and Ease of Doing Business & - & + \\
\hline 2 & FDI and Market size (GDP) & + & - \\
\hline 3 & FDI and Human Capital (EDU) & + & + \\
\hline 4 & FDI and Exchange Rate & - & - \\
\hline 5 & FDI and GDPPC & + & + \\
\hline 6 & FDI and Tax Rate & - & + \\
\hline 7 & FDI and Wage Cost & - & + \\
\hline 8 & FDI and GDP growth & + & + \\
\hline
\end{tabular}

Table 8 above presents the answer to the first research question. It can be observed that some variables such as wage cost, tax and Doing Business exhibit a positive relationship with inward FDI even when a negative relationship was expected. Meanwhile, GDP which was expected to exhibit a positive relationship turned out to be negatively related to inward FDI. Thus, this present research argues that the actual relationship between inward FDI and DB, market potential (GDPPC), human capital, tax, wage and GDP growth is a positive one, while its relationship with market size (GDP) and the exchange rate is negative.

\subsection{The extent of the Impact of the selected sets of Inward FDI location determinants on Inward FDI into India}

To successfully answer these research questions, the variables under study have been rearranged in table 8 below, starting from the variable with the highest impact on inward FDI, to the variable with the least impact on inward FDI. 
Note that interest is in the amount of change in FDI that can be attributed to such variables thus, absolute values of coefficients are used for this assessment.

Table eight presents the answer to the last research question. It shows how the location determinant variables impact FDI flow into India. As can be observed from the table, market potential (GDPPC) has the strongest impact on inward FDI, followed by Market size (GDP), Human capital (EDU), down to the least variable, wage. Thinking about these coefficients in absolute terms, the arrangement in order of importance or rank kind of makes a lot of sense. For example, one would expect the first four variables GDPPC, GDP, EDU and DB to be important variables investors may be interested in when looking for investment opportunities. The bottom four also seems to be in the right order of importance as they practice may be expected to be. Moreover, it is important to also point that the only significant variable is GDP growth at $10 \%$. Nevertheless, the widespread insignificance can be attributed to the high correlation among the explanatory variables.

Table 9. Individual Impacts of the Sets of Location Determinants on Inward FDI

\begin{tabular}{|l|l|l|}
\hline S/N & Variable & Impact (Coefficients in Absolute Value) \\
\hline $\mathbf{1}^{\text {st }}$ & Market potential (GDPPC) & 73.37 \\
\hline $\mathbf{2}^{\text {nd }}$ & Market size (GDP) & 56.68 \\
\hline $\mathbf{3}^{\text {rd }}$ & Human capital (EDU) & 8.25 \\
\hline $\mathbf{4}^{\text {th }}$ & Doing Business & 2.89 \\
\hline $\mathbf{5}^{\text {th }}$ & GDP growth & 0.57 \\
\hline $\mathbf{6}^{\text {th }}$ & Tax & 0.29 \\
\hline $\mathbf{7}^{\text {th }}$ & Exchange Rate & 0.17 \\
\hline $\mathbf{8}^{\text {th }}$ & Wage & 0.14 \\
\hline
\end{tabular}

\subsection{Implications of Findings}

The results obtained from this research would mean some radical changes to policies targeted towards attracting foreign investors into India. It was big news when it was reported that India had climbed down to 77 positions from 130 on the ease of doing business rank. The government had probably invested a lot of resources into making sure this happened. But results from this research indicates that such resources invested into such project may have been wasted. This is because, inward FDI increases in India when ease of doing business rank increases (positive relationship), and not the other way around. Furthermore, the Indian government should know that policies targeted towards GDP growth in the country are working greatly to ensure an increase in FDI, as GDP growth was found to have a significant positive impact on Inward FDI.

In addition, the government should not alter its tax rate or wage cost for the sole purpose of attracting FDI. This is because these variables were found to have a positive relationship with FDI. That is, increasing the tax rate and increasing wages attract more inward FDI. But it is advisable not to increase the existing tax rate or wage cost for the sole purpose of attracting inward FDI as there may be other macroeconomic consequences. Furthermore, the negative relationship found for exchange rate means that foreign investors are interested in a weaker Rupee to US Dollars. As such the Indian government should ensure that Rupee does not appreciate to a great extent against the USD

Moving on to other variables, where the expected outcomes were produced, it is recommended that special attention should be paid to them. GDPPC for instance produced a positive estimate. This means that how wealthy the Indian citizens are having a positive influence on inward FDI. Since rising GDP is bad for inward FDI, the only alternative to ensure adequate GDP Per Capita growth would be to enact policies targeted to control the population of the country, as GDPPC is given as GDP/Population. Similarly, Exchange rate, GDP growth and Human Capital (EDU) are other variables positively influencing inward FDI. A good policy objective would be to sustain a stable exchange rate regime, encourage local production and exports and keep improving and expanding the educational sector.

Finally, from the strength (or impact) of the individual variables, it is recommended that the government should prioritise policies to address GDP Per Capita, GDP, Education, Doing Business and GDP growth. These variables exert stronger influence (explain the higher percentage of the changes) on inward FDI

\subsection{Limitations of Research}


There are three major limitations to this study that the author regrets to announce. The first is the acute small observation used for regression. Data for all variables but Doing Business started not later than 1975-2018. That for Doing Business only started from 2006 which led to automatic data adjustment by the EViews software to only start the regression from 2006, covering only 13 years, instead of the intended observation of over 50 years. Secondly, most of the variables were highly correlated with one another, with the Exchange rate being in the centre of it all, which indicates the problem of multicollinearity. The author decided not to exclude the variable as previous studies included all the variables. Lastly, even when the assumptions of OLS are satisfied, it is still argued the approach is too simple to capture some important other technicalities associated with economic variables. For example, that of endogeneity problems.

With these limitations, there is a possibility that the results obtained in this research might be misleading. Thus, policymakers, investors and academic researchers wishing to use the results of this study to make important decisions should do so with some level of caution.

\subsection{Recommendations for Further Study}

The first important factor, future researchers should take into consideration is the availability of data for Doing Business. Since doing business is still a new concept, it is recommended for researchers to keep updating this research as more and more data are available for Ease of Doing Business Rank. Secondly, future researchers should revisit this topic, correcting for the endogeneity problem that may be present between the inward FDI and the explanatory variables used. Probably a two-stage least square method should help with addressing the endogeneity problem, but caution should be taken while selecting the instrumental variables to be used for this purpose.

\section{References}

Addison, T., \& Heshmati, A. (2004). The new global determinants of FDI flows to developing countries: The importance of ICT and democratization in Bella, M.; Becchetti, L.; Hasan, I.; Hunter, C. W. (Eds.), Monetary integration, markets and regulation. Research In Banking and Finance, 4, 151-186.

Alam, A., \& Shah, S. (2013). Determinants of foreign direct investment in OECD member countries. Journal of Economic Studies, 40(4), 515-527.

Alfaro, L. (2003). Foreign Direct Investment and Growth: Does the Sector Matter? . Harvard Business School, Working Paper.

Ang, J. B. (2009). Financial development and the FDI-growth nexus: the Malaysian experience. . Applied Economics , 41, 1595-1601.

Asiedu, E. (2002). The Determinants of Foreign Direct Investment to Developing Countries: Is Africa Different? World Development, $30(1)$.

Asiedu, E. (2005). Foreign Direct Investment in Africa: The Role of Natural Resources, Market Size, Government Policy, Institutions and Political Instability. Asiedu, E. (2005), Foreign Direct Investment in Africa: The Role of Natural Resources, Market Size, Government Policy, Insti UNU- WIDER, Finland.: Asiedu, E. (2005), Foreign Direct Investment in Africa: The Role of Natural Resources, Market Size, Government Policy, Institu World Institute for Development Economics Research.

Asteriou, D., \& Hall, S. G. (2011). Applied Econometrics (2nd ed.). Basingstoke: Macmillian.

Bajpai, N., \& Sachs, J. (2000). Bajpai, N. and Sac Foreign Direct Investment in India: Issues and Problems. Development Discussion Paper. 759. Cambridge. MA: Bajpai, N. and Sachs, J.D., 2000. Foreign Direct Investment in India: Issues and Problems. Development Dis Harvard Institute for International Development. Harvard University. Cambridge. MA. 
Barros, C. P., Caporale, G. M., \& Damásio, B. ((2013). "Foreign Direct Investment in the Asian Economies." EconomicWorking Paper 13-20. London: Brunel University.). Foreign Direct Investment in the Asian Economies. Barros, C. P.; Caporale, G. M. and Damásio, B. (2013). "Foreign Direct Invest Economics and Finance Working Paper, 13-20.

Belderbos, R., \& Carree, M. (2002). The Location of Japanese Investments in China: Agglomeration Effects, Keiretsu, and Firm Heterogeneity. Keire Journal of the Japanese and International Economies, K16(2), 194-211.

Belkhodja, O., Mohiuddin, M., \& Karuranga, E. (2016). The determinants of FDI location choice in China: a discretechoice analysis. 1241-1254. doi: https://doi.org/10.1080/00036846.2016.1153786

Belkhodja, O., Mohiuddin, M., \& Karuranga, E. (2017). The determinants of FDI location choice in China: a discretechoice analysis. APPLIED ECONOMICS, 49(13), 1241-1254.

Bevan, A., \& Estrin, S. (2004). The determinants of foreign direct investment into European transition economies. Journal of Comparative Economics, 32(4), 775-787.

Bhattacharya, A., Montiel, P., \& Sharma, S. (1996). Bhattacharya, A., Montiel Capital Flows to Sub-Saharan Africa: An Overview of Trends and Determinants. Washington DC: World Bank.

Birsan, M., \& Buiga, A. (2009). FDI determinants: Case of Romania. Transition Studies Review, 15(4), 726-736.

Blomström, M., \& Lipsey, R. E. ( 1991). Firm Size and Foreign Operations of Multinationals. The Scandinavian Journal of Economics , 93(1), 101-107.

Boateng, G. O., Boateng, A. A., \& Bampoe, H. S. (2015). MICROFINANCE AND POVERTY REDUCTION IN GHANA: EVIDENCE FROM POLICY BENEFICIARIES. REVIEW OF BUSINESS AND FINANCE STUDIES, 6(1).

Botric, V., \& Škuflic, L. (2006). Main Determinants of Foreign Direct Investment. Transition Studies Review, 13(2), 359-377.

Breen, M., \& Gillanders, R. (2011). Corruption, Institutions and Regulation. UCD Centre For Economic Resear Working Papers Series.

Broadman, H. G., \& Sun, X. (1997). The Distribution of Foreign Direct Investment in China. World Economy, 20(3), $339-361$.

Buch, C. M., \& Lipponer, A. (2004). 'FDI versus Cross-border Financial Services: The Globalisation of German Banks. Discussion Paper No. 5.

Buckley, P. J., \& Casson, M. (1976). The Future of the Multinational Enterprises. London: Macmillan.

Campos, N., \& Kinoshita, Y. ( 2002). Foreign Direct Investment as Technology Transferred: Some Panel Evidence from the Transition Economies. Campos, N.F., and Y. Kinoshita. 2002. "Foreign Direct Investment as Technology Transferred: SoWorking Paper no. 438.

Cantwell, J. A. (1989). Technological Innovation and Multinational Corporations. Oxford: Basil Blackwell.

Carkovic, M., \& Levine. (2002). CarkoviDoes foreign direct investment accelerate economicgrowth? Working Paper. Opgeroepen op Febuary 10, 2017, van Carkovic, M., \& Levine. (2002). Does foreign direct investment accelerate economicgUniversity of Minnesota Department of Finance: Carkovic, M., \& Levine. (2002). Does foreign direct investment accelerate econhttp://www.ssrn.com/abstract=314924. 
Cassidy, J. F. (2002). Japanese Direct Investment in China: Locational Determinants and Characteristics. New York: Rutledge.

Caves, R. E. (1996). Multinational enterprise and economic analysis. Cambridge: Cambridge University Press.

Chakraborty, C., \& Nunnenkamp, P. (2008). Economic Reforms, Foreign Direct Investment and Economic Growth in India: A Sector Level Analysis . World Development, 36(7), 1192-1212.

Chen, C. (1996). Regional Determinants of Foreign Direct Investment in Mainland China . Journal of Economic Studies , 23(2), 18-30.

Chen, E. (1983). Multinational Corporations Technology and Employment. London: Macmillan.

Cheng, L. K., \& Kwan, Y. K. (2000). What are the determinants of the locationof foreign direct investment: The Chinese experience. Cheng, L. K., \& Kwan, Y. K. (2000). What are the determinants oJournal of InternationalEconomics, 51, 379-400.

Chowdhury, A., \& Mavrotas, G. (2006). FDI and growth: What causes what? The world economy. United Nations University.

Corcoran, A., \& Gillanders, R. (2015). Foreign direct investment and ease of doing business. Review of World Economics, 151(1), 103 - 126.

Corcoran, A., \& Gillanders, R. (2015). Foreign direct investment and the ease of doing business. Review of World Economics, 151(1), 103-126.

Das, D. (2014). China and the Asian Economies: Interactive Dynamics, Synergy and Symbiotic Growth. London: Routledge.

Dauti, B. (2009). Determinants of Foreign Direct Investment in Macedonia. Evidence from times series 1994-2008, Proceeding of FIKUSZ'09 Symposium for Young Researchers. Dauti Bardhyl, (2009), Determinants of Foreign Direct Investment in Macedonia. Evidence from times series 1994-2008, Proceeding of FIKUSZ'09 Symposium fo Budapest Hungary: Dauti Bardhyl, (2009), Determinants of Foreign Direct Investment in Macedonia. Evidence from times series 1994-2008, Proceeding of FIKUSZ’09 SymposiuBudapest Tech Keleti Karoly Faculty of Economics .

Djankov, S., Freund, C., \& Pham, C. S. (2010). Trading on Time. The Review of Economics and Statics, 92(1), 166 173.

Djankov, S., McLiesh, C., \& Ramalho, R. (2006). Regulation and Growth. The World Bank.

DU, J., LU, Y., \& TAO, Z. (2008). FDI LOCATION CHOICE: AGGLOMERATION VS INSTITUTIONS. INTERNATIONAL JOURNAL OF FINANCE AND ECONOMICS, 13, 92-107 .

Dunning, J. H. (1973). The determinants of international production. Oxford Economic Papers.

Dunning, J. H. (1988). The theory of international production. International Trade Journal, 1, 21-66.

Dunning, J. H. (1998). Location and the multinational enterprise: A neglected factor? Journal of International Business Studies, 29(1), 45-66. 
Dunning, J. H., \& McQueen, M. (1982). DunThe Eclectic Theory of the Multinational Enterprise and the International Hotel Industry', in Rugman A. (ed.), New Theories of Multinational Enterprise. Dunning J.H. and McQueen M. (1982), 'The Eclectic Theory of the Multinational Enterprise and the InternationNew York:: Dunning J.H. and McQueen M. (1982), ‘The Eclectic Theory of the Multinational Enterprise and the InternatioSt. Martin's press.

Dunning, J., \& Narula, R. (1996). The investment development path revisited: some emerging issues. In: Dunning, J.H., Narula, R. (Eds.), Foreign Direct Investment and Governments. London: Routledge.

Erdal, F., \& Tatoglu, E. (2002). Locational Determinants of Foreign Direct Investment in an Emerging Market Economy: Evidence from Turkey. Multinational Business Review, 10(1).

Fedderke, J., \& Romm, A. ( 2006). Growth impact and determinants of foreign direct investment into South Africa, 1956-2003. Economic Modeling, 23(5), 738-760.

Froot, K., \& Stein, J. (1991). Exchange Rate and Foreign Direct Investment: An Imperfect capital Markets Approach. Quaterly Jounal of Economics, 1191-1217.

Fung, K. C., Iizaka, H., \& Parker, S. (2002). Determinants of U.S. and Japanese Direct Investment in China. Journal of Comparative Economics , 30(3), 567-578.

Galán, J. I., \& González-Benito, J. ( 2006). Ga Distinctive determinant factors of Spanish FDI in Latin America. Journal of World Business, 41(2), 171-189.

Gillanders, R., \& Whelan. (2010). Open For Business? Institutions, Business, Environment and Economic Development. Working Papers 201040.

Gola, K., Dharwal, M., \& Agarwal, A. (2013). Role of Foreign Direct Investment in the Development of Indian Economy. Gola, K.R., Dharwal, M. and Agarwal, A., 2013. Role of Foreign DiGyanpratha- ACCMAN Journal of Management, 5(1).

Government of India. (2012). Foreign Direct Investment Policy. Mubai: Ministry of Commerce and Industry, Department of Industrial Policy and Promotion.

Granger, C. (1980). Testing for causality: A personal viewpoint. Journal of Economic Dynamics and Control, 2, 329352.

Gujarati, D. N., \& Porter, D. C. (2010). Essentials of Econometrics. New York: McGrall-Hill/Irwin.

Hargreaves, C. P. (1994). Non-Stationary Time Series Analysis and Cointegration (Advanced Texts in Econometrics). Oxford: Oxford University Press.

He, C. (2001). Locational choices and export decisions of foreign manufacturing enterprises in China. Tempe: He, C. (2001). "Locational choices and export decisions of fo Unpublished doctoral dissertation, Arizona State University.

Head, K., \& Ries, J. (1996). Inter-City Competition for Foreign Investment: Static and Dynamic Effects of China's Incentive Areas. Journal of Urban Economics, 40(1), 38-60.

Hymer, S. (1960). The International Operations of National Firms: A Study of Direct Foreign Investments. Cambridge, MA: MIT Press. 
Indian Express. (2005, November 11). Indian Policy on FDI. Mubai.

Insah, B. (2013). Foreign direct investment and economic growth in Ghana. International Journal of Economic Practices and Theories, 3(2), 2247 - 7225.

Janicki, H. P., \& Wunnava, P. V. (2004). Determinants of Foreign Direct Investment: Empirical Evidence from EU Accession Candidates. Applied Economics, 36(5), 505-509.

Jayasuriya, D. (2011). Improvements in the World Bank's Ease of Doing Business Rankings; Do they translate into greater foreign direct investment inflows? Development Policy Centre Discussion Paper, 8.

Johansen, S. (1988). Statistical analysis of cointegration vectors. Journal of Economic Dynamics and Control, 12(2), $231-254$

Kinuthia, B. K., \& Murshed, S. M. (2015). FDI determinants: Kenya and Malaysia compared. Journal of Policy Modeling, 37, 388-400.

Kyrkilis, D., \& Pantelidis, P. (2003). Macroeconomic Determinants of Outward Foreign Direct Investment. International Journal of Social Economics, 30, 827-836.

Lokesha, B., \& Leelavathy, D. (2012). Determinants of Foreign Direct Investment: a macro perspective. Lokesha B.K., Leelavathy, D.S., 2012. Determinants of FoShri Ram Centre for industrial Relations and Human Resources.

Majumdar, B. ( 1980). A case study of the industrial organization theory of Foreign Direct Investment. Weltwirtschaftliches Archive, No. 2.

Makino, S., Lau, C., \& Yeh, R. (2002 ). Asset-exploitation versus asset-seeking: Implications for location choice of foreign direct investment from newly industrialized economies. Journal of International Business Studies, 33(3), Makino S, Lau C.M. and Yeh, R.S. (2002), 'Asset-exploitation versus asset-seeking: Implications for location choice of foreign direct investm403-421.

Mohiuddin, M., \& Su, Z. (2013). Manufacturing Small and Medium Size Enterprise's Offshore Outsourcing and Competitive Advantage: An Exploratory Study on Canadian Offshoring Manufacturing SMEs. Mohiuddin, M., and Z. Su. (2013). "Manufacturing Small and Medium Size Enterprise's Offshore OutsourcinJournal of Applied Business Research, 29(4), 1111-1130.

Moran, T. H., Graham, E. D., \& Blomsstrom, M. ( 2005). Does Foreign Direct Investment Promote Development? . Moran, T.H., Graham, E.D. and Blomsstrom, M., 2005. Does Foreign DirecWashington. DC. 411.: Moran, T.H., Graham, E.D. and Blomsstrom, M., 2005. Does For Institute for International Economics-Center for Global Development.

Morris, R., \& Aziz, A. (2011). Ease of doing business and FDI inflow to Sub-Saharan Africa and Asian countries. Cross Cultural Management: An International Journal.

Moshirian, F. (1997). Foreign Direct Investment in Insurance Services in the United States. Journal of Multinational Financial Management, 7, 159-173.

Moshirian, F. (2001). International Investment in Financial Services. Journal of Banking and Finance, 25, 317-337. 
Nair-Reichert, U., \& Weinhold, D. (2001). Causality tests for cross-country panels: Anew look on FDI and economic growth in developing countries. Nair-Reichert, U., \& Weinhold, D. (2001). Causality tests for cross-coOxford Bulletin of Economics and Statistics, 63(2), 153-171.

Nangpiire, C., Rodrgues, R. G., \& Adam, I. O. (2018). Ease of doing business and foreign direct investment inflow among Sub-Sahara African countries. International Journal of Business and Emerging Markets, 10(3), 289 302.

Nonnenberg, M., \& Mendonca, M. (2004). The determinants of direct foreign investment in developing countries. Nonnenberg, M. and Mendonca, M., (2004) The determinants of direct Proceedings of the 32th Brazilian Economics Meeting. Brazil.

Noorbakhsh, F., Paloni, A., \& Youseff, A. (2001). Human Capital and FDI Inflows to Developing Countries: New Empirical Evidence. World Development, 29, 1593-1610.

Odozi, V. A. (1995). An overview of foreign investment in Nigeria 1960 - 1995. Occasion Paper, No.11.

Office for National Statistics. (2017). Key Economic Time Series Data. Opgehaald van www.ons.gov.uk: http://webarchive.nationalarchives.gov.uk/20160105160709/http://www.ons.gov.uk/ons/siteinformation/using-the-website/time-series/index.html

Pan, Y. (2003). The inflow of foreign direct investment to China: the impact of country-specific factors. Journal of Business Research, 56, 822-833.

Phillips, P. C., \& Person, P. (1988). Testing for Unit Roots in Time Series Regression. Biometrika, 75, 335-346.

Piwonski, K. (2010). Does the 'Ease of Doing Business' In a Country Influence its Foreign Direct Investment Inflows? Honors Projects in Finance, 13.

Porter, M. (1990). The Competitive Advantage of Nations. New York: Free Press.

Raff, H., \& Von der Ruhr, M. ( 2001). 'Foreign Direct Investment in Producer Services: Theory and Empirical Evidence. Opgeroepen op January 17, 2017, van Raff, H. and Von der Ruhr, M (2001), 'Foreign Direct Investment in Producer S http://www.cesifo.de/pls/guestci/download/F5534/598.PDF.

Ranjan, V., \& Agrawal, G. (2011 ). FDI inflow determinants in BRIC countries: a panel data analysis. International Business Research , 4(4), 255-263.

Root, F. R., \& Ahmed, A. (1979). Empirical Determinants of Manufacturing Direct foreign Investment in Developing countries. Economic Development and Cultural Change, 27, 751-767.

Rosetta, M. A. (2011). Ease of doing business and FDI inflow to Sub-Saharan Africa and Asia countries: Cross Cultural Management. An International Journal, 18(4), 400 - 411.

Saunders, M., Lewis, P., \& Thornhill, A. (2012). Reasrch methods for business students. Essex: Pearson Education Limited.

Scaperlanda, A., \& Maurer, L. (1969). The determinants of US Direct investment in the EEC . American Economic Review, 59, 558-568. .

Seetanah, B., \& Khadaroo, A. ( 2007). Seetanah, B. and Foreign direct investment and growth: new evidences from Sub-Saharan African countries. Paper Presented at Economic Development in Africa 2007. Seetanah, B. and Khadaroo, A.J., 2007. Foreign direct investment and growth: new evidences from SCSAE Conference. 
Sethi, D., Guisinger, S. E., Phelan, S. E., \& Berg, D. M. (2003). Trends in Foreign Direct Investment Flows: A Theoretical and Empirical Analysis. Journal of International Business Studies, 34(4), 315-26.

Sharmiladevi, J., \& Saifilali, M. (2013). Sharmiladevi, J.C. an An Empirical Examination of the Determinants of Foreign Direct Investment in India. Sharmiladevi, J.C. and Saifilali, M.I., 2013. An Empirical Examination of the Determi The International Journal of economics and Business Studies.

Singhania, M., \& Gupta, A. (2011). Determinants of foreign direct investment in India. Journal of International Trade Law and Policy, 10(1), 64-82.

Terpstra, V., \& Yu, C. M. (1988). 'Determinants of Foreign Investment of US Advertising Agencies. Journal of International Business Studies, 19, 33-46.

Uddina, M., Chowdhuryb, A., Zafarc, S., Shafqueb, S., \& Liu, J. (2019). Institutional determinants of inward FDI: Evidence from Pakistan. International Business Review, 28, 344-358.

UKTI. (2014). UK attracts highest levels of inward investment on record. LONDON: UKTI.

Vogiatzoglou, K. (2016). Ease of Doing Business and FDI Inflows in ASEAN. Journal of Southeast Asian Economies, $33(3), 343-363$.

Wadhwa, K., \& Reddy, S. S. (2011). Foreign Direct Investment into Developing Asian Countries: The Role of Market Seeking, Resource Seeking and Efficiency Seeking Factors. International Journal of Business and Management, 6(11).

Wang, Z. Q., \& Swain, N. J. ( 1995). The Determinants of Foreign Direct Investment in Transforming Economies: Empirical Evidence from Hungary and China. Weltwirtschaftliches Archiv , 131(2), 359-382.

Wei, Y., \& Liu, X. (2001). Foreign Direct Investment in China: Determinants and Impact. Cheltenham: Edward Elgar.

Wei, Y., Liu, X., Parker, D., \& Vaidya, K. (1999). The Regional Distribution of Foreign Direct Investment in China. Regional Studies , 33(9), 857-867.

World Bank. (1996). World debt tables: external financing for developing countries. Washington DC.: The World Bank.

Xu, Z., \& Yeh, A. (2013). Origin Effects, Spatial Dynamics and Redistribution of FDI in Guangdong, China. Tijdschrift Voor Economische En Sociale Geografie , 104(4), 439-455.

Yin, F., Ye, M., \& Xu, L. (2014). Location Determinants of Foreign Direct Investment in Services: Evidence from Chinese Provincial-level data. London: Asia Research Centre, LSE.

Zhang, X., \& Yuk, H. P. ( 1998). Determinants of Hong Kong manufacturing investment in China: a survey. Marketing Intelligence and Planning, 16(4).

Zhao, H., \& Zhu, G. (2000). Location Factors and Country- Of-Origin Differences: An Empirical Analysis of FDI in China. Multinational Business Review , 8(1), 60-73. 